\title{
Pilot training and English as a lingua franca: some implications for the design of Aviation English for ab initio flight training courses
}

Treinamento de voo e o inglês como lingua franca: recomendações para o desenvolvimento de cursos de inglês para aviação na formação inicial do aviador.

Markus BIESWANGER (University of Bayreuth) ${ }^{1}$ Malila Carvalho de Almeida PRADO (FJUT) ${ }^{2}$ Jennifer ROBERTS (ERAU) ${ }^{3}$

\section{ABSTRACT}

This paper revisits discussions on needs assessment of language courses for non-native English speakers (NNES) prior to ab initio flight training, or initial flight training, in English-speaking environments. The growing need for pilots in areas of the world where English is traditionally not the native language of the population and the fact that many of them attend flight school in English-speaking countries have increased the demand for such courses. Important questions are what communicative competencies the future flight students need and how current research on English as a lingua Franca (ELF) can inform the design of English for flight training courses. The paper presents the results of a study based on semistructured interviews with six non-native speaking professional pilots who received ab initio training in English-speaking countries. The analysis suggests that NNES ab initio flight students need to be equipped with the right mix of communicative strategies often summarized as ELF awareness and a sufficient amount of English language proficiency.

Keywords: Ab Initio Pilot Training, English for Flight Training Courses, Communicative Strategies, English as a Lingua Franca.

\section{RESUMO}

Este artigo retoma discussões sobre a análise de necessidades em cursos de línguas para falantes não nativos antes da formação inicial de aviador em países de língua inglesa. A carência por pilotos em áreas do mundo onde o inglês não é tradicionalmente a língua oficial e o fato de que muitos buscam a formação inicial em países de língua inglesa aumenta a demanda por tais cursos. Algumas questões relevantes se referem a quais competências comunicativas são necessárias a esses alunos e como a atual pesquisa sobre o Inglês como Língua Franca (English as a Lingua Franca - ELF) pode auxiliar no desenvolvimento de cursos para esse público. $\mathrm{O}$ artigo apresenta os resultados de um estudo baseado em entrevistas semi-

\footnotetext{
${ }^{1}$ University of Bayreuth, Bayreuth, Bavaria, Germany. Department of English and American Studies - English Linguistics; ORCID: https://orcid.org/0000-0001-6934-4707; markus.bieswanger@uni-bayreuth.de

${ }^{2}$ Fujian University of Technology, Fuzhou, Fujian, China. School of Humanities; ORCID: https://orcid.org/0000-0001-62816759; malilaprado@hotmail.com

${ }^{3}$ Embry-Riddle Aeronautical University, Daytona Beach, Florida, United States of America. College of Aeronautics;

ORCID: https://orcid.org/0000-0003-4552-9576; roberj62@erau.edu
} 
estruturadas com seis pilotos não nativos que receberam o treinamento inicial de voo em países de língua inglesa. A análise sugere que alunos pilotos não nativos precisam estar equipados com uma boa combinação de estratégias comunicativas frequentemente resumidas como conscientização de ELF e um nível mínimo de proficiência em língua inglesa.

Palavras-Chave: Formação Inicial para Pilotos, Cursos de Inglês Preparatório para Treinamento de Voo, Estratégias Comunicativas, Inglês como Língua Franca (ELF)

\section{Introduction}

Aviation is arguably the most global of all industries. Due not only to the fact that the industry makes worldwide transport affordable and convenient, the aviation industry brings together individuals from different linguistic and cultural backgrounds to participate in operations, professional development, and training. Regardless of an individual's first language, aviation training is often conducted in English, from recurrent and refresher training activities for professionals, to initial training for new pilots. The latter is known as ab initio flight training, and can consist of training students with no prior experience with flight to the point of licensing them as commercial pilots.

To become a pilot, students must demonstrate competencies in both conceptual knowledge of aviation and in flying the airplane. The initial step is usually to complete a ground school course, which includes typical classroom lessons on flight theory and aircraft systems taught by a ground school instructor. While online ground school courses are an option, most opt for in-person classes which parallel any other professional learning environment, i.e. there is a physical classroom full of students, a teacher in the front of the room, and students who are expected to comprehend, process, and retain a great deal of information. A successful student participates in ground school just as any other successful student participates in a class with similar dynamics - taking notes, asking questions, and studying the material. During the practical portion of flight training, students interact with flight instructors in a similar manner, including verbal demonstration of content knowledge and skill mastery. The challenge for ab initio flight students who study in English speaking countries, however, is that they must take part in these activities using a language as a lingua franca that is not their native language.

\section{State of the art}

\subsection{The Language of Ab Initio Flight Training}

In ab initio flight training, students often learn from instructors and interact with peers who may not share their first language. In these situations, English is often used as a lingua franca (ELF), defined by Seidlhofer (2005, p. 339) as "communication in English between speakers with different first languages" or Jenkins (2009, p. 200) as "the common language of choice, among speakers who come 
from different linguacultural backgrounds." Flight training is frequently conducted using English as a Medium of Instruction (EMI), particularly in English-speaking countries such as the United States or Australia, for example. Brown and Bradford (2016) define EMI as focusing centrally on the content of the course, offered to non-native English speakers (NNES) with varying levels of English language proficiency. This means that all flight students, regardless of first language, will receive the same type of instruction, use the same course materials, and participate in the same training schedule. Though the process is the same, the experience for NNES is likely to vary considerably, especially without appropriate training beforehand.

Students in an EMI course will be assessed only on their mastery of the subject content and not at all on language skills. In EMI ab initio flight training, the English language is an integral part of accomplishing the acquisition of aviation subject content and of demonstrating skill mastery, as all instruction and assessment will take place in English. In these situations, students will not just use English when flying an aircraft and communicating with air traffic control, but also as they are taught how to be a pilot in English, including both transactional knowledge and piloting skills. Flight instructors are certainly not English language teachers, nor do they receive mandatory training in strategies to accommodate NNES with varying proficiency. Teaching the English language needed to participate successfully in flight training should not be the responsibility of the flight instructor, but rather should be done by trained and well-qualified language teachers through courses designed specifically for this context.

The English language for aviation purposes is typically termed Aviation English, though the many contexts in which English is used in the aviation industry are still being defined and explored (cf., e.g., MODER, 2013, p. 227; BIESWANGER, 2016; TOSQUI-LUCKS; SILVA, 2020). While most research, training, and testing focus has thus far been given to the teaching, learning, and use of radiotelephony (RTF), English is also the common language of aircraft maintenance manuals, some refresher and recurrent safety training, and flight instruction. Each of these specialized areas, associated with specialized registers, needs tailor-made Aviation English courses, with content which reflects the learners' professional and linguistic knowledge. Ab initio flight students have minimal aviation knowledge, are being taught to fly, and have varying English language skills depending on their geographical and educational background. An experienced captain who is specifically studying to obtain an ICAO Language Proficiency score of Operational Level $4^{4}$ will not benefit from the same language training course with the same content as an ab initio flight student.

\footnotetext{
${ }^{4}$ The International Civil Aviation Organization (ICAO) is responsible for providing the aviation industry with international standards and best practices, among which are the language proficiency requirements for personnel licensing (pilots and air
} 


\subsection{Ab Initio Flight Training in English-speaking Countries}

NNES flight students may learn Aviation English in their home countries or in the Englishspeaking countries of many Flight Training Organizations (FTOs). In their home countries, students may attend in-person Aviation English courses taught by local instructors, referred to in this paper as predeparture courses. On the other hand, some students travel to the country of their FTO and participate in an Aviation English class before starting practical training. As the admission criteria and English proficiency testing requirements of ab initio flight training are still unstructured and inconsistent, students may skip language training altogether and begin flight training only to be later "grounded" due to inadequate English language ability (EMERY; GLIDDON, 2019; ROBERTS; ORR, 2020; LYNCH; PORCELLATO, this volume). In order to avoid delaying the flight training process, FTOs prefer to admit students who already have the language skills needed for flight training, as instructors and aircraft are typically limited (EMERY, 2015; ROBERTS; ORR, 2020). Many flight students who travel to the United States for training, for example, have a contract with an airline that is paying them to do their training and return home to fly (DUSENBURY; BJERKE, 2010), so time spent on language training at the FTO is seen as wasteful and inefficient.

If a student commences practical flight training without the requisite language skills, it is, above all, a safety risk. In the United States, where an estimated 40,000 international flight students train (HOFFMAN, 2020), meeting the Aviation English Language Standards (AELS) outlined in the Federal Aviation Administration's (FAA, 2013) AC 60-28B is considered demonstration of adequate language proficiency. The AELS are meant to be equivalent to ICAO's Operational Level 4, but the instrument used to make this assessment varies tremendously, and the training to prepare for this testing scenario is unregulated. As the process to evaluate the AELS is unstandardized in the United States, FTOs and the individuals within those organizations (e.g. flight instructors, FAA examiners, aviation safety inspectors) share the burden of testing NNES flight students without effective training to do so (EMERY; GLIDDON, 2019).

In 2017, two student pilots in Canada had an unfortunate mid-air collision while flying solo. The accident investigation agency concluded that lack of English proficiency was a contributory cause and recommended that student pilots not fly solo before passing an Aviation English test ${ }^{5}$. This accident illustrates why FTOs need a way to reliably assess if a flight student has adequate English language

traffic controllers). On a scale from 1 to 6 , operational Level 4 is the minimum required to allow pilots and air traffic controllers to operate internationally.

${ }^{5}$ Available at: < https://www.bst-tsb.gc.ca/eng/rapports-reports/aviation/2017/a17q0030/a17q0030.html>. Access: 30 jul 2020. 
proficiency to perform required flight training tasks, such as flying solo. Using a test designed for the ICAO Language Proficiency Requirements (LPRs) is problematic and an unreliable indicator of flight training preparedness, as the ICAO LPRs are specifically written to evaluate the language proficiency of licensed pilots and controllers in the RTF domain (ICAO, 2010), thus leaving out many of the language requirements of $\mathrm{ab}$ initio flight training. Aviation English tests for professional pilots and air traffic controllers require some level of experience considering the technical knowledge involved (KIM, 2018) and, therefore, do not meet the needs of future aviators who may not have yet acquired that aviation expertise (EMERY, 2015; EMERY; GLIDDON, 2019).

Lynch and Porcellato (this volume) argue that an aviation screening test which looks specifically at the language proficiency needed for flight training conducted in English needs to be developed. Results of such an assessment can lead stakeholders to make decisions about admitting students who do not yet demonstrate the language proficiency needed, and guide students to seek English language training before beginning flight training, perhaps in a pre-departure format. Unlike current language proficiency evaluations done by non-language specialists without the appropriate knowledge that this task demands (EMERY; GLIDDON, 2019; FRIGINAL; MATHEWS; ROBERTS, 2020, p. 248), an assessment to evaluate language proficiency should be rated by trained language specialists.

\subsection{The Ab Initio Flight Training Domain}

Defining the domain of ab initio flight training in English-speaking environments is still a work in progress. The language needs of flight students are unique in that they need to participate in RTF communications with controllers, but also need to interact with their flight instructors, comprehend lectures from ground school instructors, and read information-dense textbooks on flight theory, aircraft systems, and airport operations (EMERY; GLIDDON, 2019; ROBERTS; ORR, 2020). Other language tasks expected of a flight student include debriefing with their flight instructor, talking with dispatchers before a flight, asking and answering questions during oral exams, talking to peers and reporting technical problems (FRIGINAL; MATHEWS; ROBERTS, 2020). These tasks take place in noisy, dynamic flight decks with air traffic controllers, in simulators with flight instructors, and in typical classroom settings with ground instructors. In and around the training aircraft, students are expected to respond to prompts from instructors, answering questions to demonstrate comprehension and confirming performance checklist tasks. It is of the utmost importance that ab initio Aviation English language training be “purposefully constructed to ensure [training programs'] validity and efficacy" (ROBERTS; ORR, 2020, p. 140). Therefore, as the the language skills needed in flight training are those of a pilot, and also those of a student, a corresponding language course should clearly incorporate aspects of English for Specific 
Purposes (ESP) methodology, but should also target some of the academic reading and listening skills present in English for Academic Purposes (EAP) courses.

To better understand this course's relevance in the current aviation industry, consider that a study of the Chinese civil aviation market found that by 2016 there were approximately 32,000 airline pilots in China, 550 of whom were foreigners (GORBOLD, 2017). It stated that the total number has been dramatically growing with a yearly average of 5,000 student pilots starting their training; $50 \%$ of these students receive their initial training in China and the other 50\% go to the United States, Canada, Australia, South Africa and England.

Both the increasing number of Chinese student pilots studying abroad and the greater demand for experienced foreign airline pilots have called the attention of international and local media. It is suggested that cross-cultural encounters in flight decks, either with professional crews or with instructor and ab initio pilots, have been problematic. More specifically, the common native English speaking (NES) instructor and the NNES student pilot's ability to successfully interact may be compromised, as flight instructors often complain not only about language barriers, but also about cultural differences that play a significant role in the training. An article of the Washington Post dated of 2018, intitled "A pilot kidnapped a foreign student and tried to deport him back to China", reported that a Chinese student pilot's limited English skills were cited as the reason for the flight instructor's behavior ${ }^{6}$. The same article reports other instructors' accounts of near air misses because foreign ab initio pilots could not understand in-flight instructions demonstrating that the problem leading to such a conflict is not rare.

\subsection{Native English Speaker and Non-Native English Speaker Interaction}

The incidents described in the last section highlight the need for cooperation between participants in the flight training communication domain who may come from different linguistic and cultural backgrounds. In these interactions, both NES and NNES are responsible for the communication's success, necessitating the use of language resources by all participants (FRIGINAL; MATHEWS; ROBERTS, 2020; KIM; ELDER, 2009). However, studies of NES x NNES interactions in areas other than aviation have pointed to a lack of cooperation particularly on the part of NES (RAJAGOPALAN, 2005).

In flight training, it is likely that a NNES flight student will interact with NES air traffic controllers and instructors. In RTF communications, Bieswanger (2013) and Kim (2018) highlighted a frequent lack of adaptation and accommodation strategies used by the NES. In busy airspace which includes heavy

\footnotetext{
${ }^{6}$ Available at: <https:/www.washingtonpost.com/news/true-crime/wp/2018/05/27/a-pilot-kidnapped-a-foreign-student-andtried-to-deport-him-back-to-china-police-say/>. Access: 30 jul 2020.
} 
flight training activity, controllers may experience frustration in communicating with NNES student pilots, believing it adds to their workload and causes congestion on the frequencies. Further, the interactions between NES instructors and NNES student pilots have been strained due to communication challenges. Ground and flight instructors generally lack the skills or strategies to accommodate their language to NNES, as "[t]hey are liable to use a fast speech rate and regional accent in addition to idioms - all of which may impede comprehension for international students" (ROBERTS; ORR, 2020, p. 133). Despite having the technical expertise, flight and ground instructors may experience some of the same frustrations as air traffic controllers in communicating with NNES students during the instructional components of flight training. Courses designed specifically to prepare for these scenarios, focusing on a view of communicative competence that goes beyond the linguistic needs to also include strategic and pragmatic competence (DAVIES, 2004) for interactions between NES and NNES (KAY, 2018; MONTEIRO, 2019; PRADO, 2019), could be helpful in addressing these challenges.

\subsection{English as a Lingua Franca in Aviation}

The use of English by NNES in the aviation industry will undoubtedly continue to increase. As the growth of aviation is more rapid in many Asian countries (BOEING, 2019) where English is not the native language of the majority of the population, Bieswanger (2019) predicted that "English will be increasingly used as a lingua franca (ELF) in the aviation community and the language background of these users will be different from ELF users in aviation in the past."

As stated earlier, we adopt the definition of ELF as "a contact language between speakers or speaker groups when at least one of them uses it as a second language" (MAURANEN, 2018, p. 8), an appropriate categorization for the flight training interactions described in Section 2. In these situations, NES and NNES must adopt certain strategies in order to foster communication when interacting; if any breakdown occurs, participants need specific strategies to overcome it. The use of these strategies is a feature of Aviation English which, aligned with Estival, Farris \& Molesworth (2016) and Bieswanger (2016), we consider to be made up of specialized registers of English used in the professional aviation community. These registers are not acquired without explicit study (BIBER; CONRAD, 2009), and must be learned by both NES and NNES. Supporting the notion that NES must also learn to communicate in the aviation domain, studies have shown that NES usually cause more misunderstandings in radio communications (KIM, 2018), particularly in the use of Standard Phraseology (a highly prescribed code to be used in routine flight operations). The same issues with speech rate, regional accents, and idioms used by flight instructors (as mentioned in Section 2) may also be seen in the RTF communication domain. 
ELF research initially focused on describing features such as phonological and lexicogrammatical patterns, similar to the description of varieties in variational linguistics, which would, for example, allow for the definition of a phonological ELF core (JENKINS, 2000) and the proposal of ELF features that could be taught to NNES (cf., e.g., JENKINS, 2002; SEIDLHOFER, 2004). This view has given way to an understanding that ELF is more fluid and flexible (see JENKINS, COGO \& DEWEY, 2011) and that there is no universal set of features that could be taught to NNES (JENKINS, 2015; cf. also SIFAKIS, 2019). This switch from product (features) to process (strategies) has largely resulted from empirical studies drawn on corpora compiled in ELF environments, with investigations revealing the importance of aspects such as adaptation, accommodation, explicitness, and other interactional processes (MAURANEN, 2018). Such findings have shed light on other conceptual reformulations, like the shift from viewing native speaker norms as correct to a perspective that sees language users constructing communication towards mutual understanding (KAUR, 2019).

It has been shown that in many ELF interactions, participants engage in the co-construction of meaning, deploying certain communicative strategies such as, but not restricted to, "repetition, reformulation, confirmation and clarification requests, comprehension checks, and code-switching" (KAUR, 2019). Most of these processes, however, are undesirable in Aviation English, particularly RTF communication, which is to a large extent standardized and focused on accuracy, efficiency, and effectiveness. What the recent and ongoing reconceptualization of ELF and the implications of the fact that many believe now that 'ELF, at the discourse or variety level ('ELF-1' in Jenkins' terminology), is not teachable" (Sifakis 2019: 295) mean for ab initio pilot training and the preparation of future students before flight school is to be discussed in Section 5 .

\section{Research Questions}

This study is concerned with the communicative skills NNES flight students need in order to succeed in $\mathrm{ab}$ initio flight training in English-speaking environments, effectively the entry point into their new professional community. The study builds upon previous needs analysis on the most relevant language tasks in ab initio flight training courses, as outlined above, and explores the experiences of NNES pilots who successfully completed flight training using ELF. The future development of English for flight training language courses will most likely benefit from the discussion of the results in relation to recent research on the repositioning of ELF in language teaching.

In the study we have collected and analyzed data in order to address the following research questions: 
1. What communicative skills are necessary for NNES ab initio flight students in English-speaking environments?

2. How can current research on ELF inform the design of English courses for NNES ab initio flight students?

To answer these questions, six NNES professional pilots were asked to participate in semistructured interviews about their experiences regarding communication during flight training in an English-speaking country. In addition to their language backgrounds and flight training scenarios, these pilots were selected because they used ELF to successfully complete their training abroad, and continue to use ELF in the professional aviation community today.

\section{Data and Methodology}

For the study proposed here, a qualitative method was used. Three Brazilian pilots and three Chinese pilots who went to an English-speaking country for ab initio flight training were interviewed. Two of the Brazilian pilots currently fly corporate jets as first officers, often internationally; the other flies internationally as a first officer in a major airline company based in Brazil. The language proficiency of all three Brazilians has been rated as ICAO Extended Level 5 by the Brazilian civil aviation authority (Agência Nacional de Aviação Civil - ANAC). The three Chinese pilots fly for a domestic commercial airline in China; however, they are qualified to fly with foreign pilots, who compose almost $50 \%$ of the total number of captains in the company. Their qualification is granted through the maintenance of ICAO Operational Level 4 as certified by the Chinese aviation agency (Civil Aviation Administration of China $-\mathrm{CAAC})$.

The procedures involved in qualifying as a pilot in Brazil and in China differ to a great extent. In Brazil, ab initio training is self-sponsored and often conducted in flight schools mostly located in the south or southeast of Brazil. Although some flight schools in Brazil include English courses in their syllabi, they are usually conducted at the end of the training when pilots are already licensed (c.f. BOUFLEUER, 2019). When ready to apply for a job, candidates must have a minimum of 500 flight hours with any college degree, or 1,500 flight hours without it, and an ICAO Operational Level 4 rating. This requirement is among the factors that attract some students to seek flight instruction in the United States instead of Brazil, as they can presumably learn how to fly, get an FAA licence - which is often considered prestigious by many countries in the world (FRIGINAL; MATHEWS; ROBERTS, 2020), including those in South America - and learn English at the same time. However, there is no mandatory test to check the English 
proficiency of prospective students before they enroll in a flight school in the United States (see Section 2.3).

China's rapidly increasing aviation market also demands more pilots, but restricted airspace and lack of facilities in China have resulted in airlines actively sending students to countries like the United States for training (DUSENBURY; BJERKE, 2013). Chinese airline companies establish partnerships with universities, looking for candidates in the last year of college. The requirements are based on their medical records and English proficiency level, measured by an in-house general English test given by the university. Provided that candidates meet the requirements, they can apply for the job and receive full sponsorship to receive flight training abroad (GORBOLD, 2017), returning to China afterwards to work as commercial airline pilots.

The interviews with the informants were semi-structured; while the questions needed to be guided by the objectives of the study, we still allowed for the interview to evolve according to the interviewee's response. The basic questions were as follows:

1. What is your nationality? What is your first language?

2. Where did you receive your flight training?

3. Did you speak English before your flight training? If so, was your English level sufficient during your training?

4. Did you need to take an English test before flight training? Why? What kind of test?

5. How was your experience with English in the country where you received flight training? Can you remember any problems you had?

The interviews were conducted in English by one of the authors, Malila Prado, through video calls recorded with the interviewees' authorization. Each lasted around 30-40 minutes.

\section{Findings and Discussion}

As previously stated, ELF contexts are interactions in which English is used by at least one speaker for whom it is not their first language. In this presentation of the data and analysis, we aim to demonstrate the findings related to the challenges that the informants faced as NNES in English-speaking countries while learning and developing professional piloting skills. Following this presentation, we consider the strategies employed by the informants in their stay abroad to offer, finally, some recommendations for language courses to prepare ab initio flight students using ELF. 
All three Brazilian pilots opted for self-sponsored training in the United States. They were 18-20 years old at the time of their training, which took from 10 to 14 months to complete. Though they did not have any formal assessment, two of them declared that they had a basic level of English when they started the training. The other pilot had previously studied in New Zealand and claimed to have an upperintermediate English level when he went to the United States. They did not receive any formal Aviation English instruction before going abroad.

All three Chinese pilots received flight training sponsorship by an airline company in China. They spent from 12 to 18 months receiving flight training abroad. One of the pilots went to South Africa, another to Canada and the third one to the United States. They were recruited by the airline company in their last year of college where they were studying civil aviation or agricultural sciences. The two who majored in civil aviation did not undergo any Aviation English training before moving abroad; the one studying agricultural sciences went through 3 months of intensive training, in Mandarin, on aviation fundamentals such as flight theory, weather, and flight rules, and he also had some Aviation English classes. Two out of the three Chinese pilots underwent a proficiency test in general English as a prerequisite to finishing college in China before going abroad. The pilot who did not take a proficiency test was approved by inhouse tests at the university.

\subsection{Interactions outside of flight training}

Although the pilots went to different countries, they all reported very similar language experiences. The first challenge was to cope with the everyday routine, such as ordering food, managing schedules with the school's administration, or talking with the landlord about problems in the apartment (cf. CABAU, 2014). Even those who had a better English proficiency level reported struggling with accents or unfamiliar language use. One stated that locals used a type of English "not taught at school," to the point of generalizing that "Americans have a local language." They all acknowledged some difficulty of adapting to the speech rate of NES, particularly outside the school environment.

The formation of their community included those with whom they lived, particularly housemates who shared their first language, which, according to them, slowed their process of learning English. Still, they felt more confident knowing that they had partners to count on for extra studies or difficulties they encountered. They also showed an inclination to be a part of the host community by participating in some social events. One of the pilots expressed that "learning a language is learning the culture", and attended services at the community church, as it was the only social activity available in a remote location near Dallas, Texas. One of the Brazilian pilots reported he almost quit because of his poor English communication skills at the beginning of his stay. According to him, he could not understand anyone - 
from the receptionist to the instructors - at the flight school. As a way of improving this proficiency, he started spending the day at the flight school in order to have contact with people from different nationalities. He believes these interactions enhanced his English skills.

All participants agreed that these social interactions contributed to their English development, evident in both the more colloquial encounters and in flight training. However, the interviewees described other students who were not keen on participating in the local community and avoided contact with NES unless necessary. These students did not take advantage of the fact that, other than learning how to fly, they were also there to improve their English. They focused exclusively on acquisition of the aviation content, and though most eventually obtained their licenses, it was reported that they took considerably longer than the interviewees. A few students even failed their check rides (tests in flights) and returned to their home countries without reaching their objectives (see the account about the student in South Africa below).

The reports resemble the findings of Kalocsai (2009, p. 42) that the participants of a certain community, when socializing outside the school environment, "learn to use ELF in ways that make them efficient and proud communicators". It is worth mentioning that, despite the difficulties in social interactions, compounded by their lack of experience living abroad, the interviewees received assistance from the flight school personnel and these socialization situations, however important they might be, were not safety-critical.

\subsection{Interaction inside of flight training}

At school, the interviewees indicated that many instructors seemed to understand their needs. One of the the students reported that at his flight schools in Texas, which trained mostly Chinese students, instructors "spoke slowly". This same interviewee was the only pilot to receive training in the United States that included a two-week general English course before starting flight lessons. He also described simulated Visual Flight Rules (VFR) communication lessons in which the instructor would tell the students possible scenarios to work on their radio skills. The participant justified this extra attention to communication skills given by the instructors by the fact that "some students couldn't pass the test not because they didn't know how to fly, but because their English was so bad and they couldn't be released to their solo flights."

One of the Brazilian pilots remembered being particularly relieved when he was assigned an instructor who shared his nationality. He pointed out that, when he was interacting with the controller, the instructor knew how to address his personal difficulties and his English, particularly his pronunciation. He stated that his previous instructors had never mentioned anything about his language skills, even 
though the air traffic controller repeatedly asked for clarification. He implied that, because the students at his Florida-based flight school were mostly from India, China or South America, the instructors were probably familiar with foreign accents and understood everyone, a fact that also exempted instructors from correcting the students' pronunciation idiosyncrasies.

One of the pilots complained about a Greek instructor who, rather than accommodating his speech, preferred to mime or point at things. When asked about the nationalities of their flight and ground instructors, the interviewees mentioned that, because of the amount of international students, some flight schools hired more NNES to work as instructors. As a result, the schools allegedly saw an improvement in the students' performance. The pilots who trained in the United States confirm that dealing with NNES was better, as they "spoke slowly". There were even Chinese flight instructors in the South Africa based flight school, according to the informant who received flight instruction there, but not enough to match the number of Chinese student pilots.

Two of the pilots expressed a certain regret in not completing ab initio flight training in China, as they believe the language barrier hindered the development of their flying skills. They felt overloaded having to deal with language and learning how to fly simultaneously (cf. FARRIS, 2007). According to all of the interviewees, they witnessed many cases of students who either did not complete their flight training or failed because of insufficient English skills. For example, the South African-licensed participant mentioned that some of his fellow students did not complete their training successfully and changed to other technical courses when they returned to China. Because the airline company had invested money in their flight training, they ended up working as flight dispatchers, aircraft maintenance technicians or in other non-pilot jobs at the airline.

These accounts largely confirm the conclusions that Roberts and Orr (2020) (see Section 2) come to about NES flight instructors' lack of accomodation skills. Perhaps because of these issues, some schools have adopted the strategy of hiring instructors of different nationalities to promote mutual understanding. However, merely hiring NNES instructors is not an effective solution to the problems mentioned here, particularly considering the experience with the Greek instructor. Students paired with a flight instructor who shares their first language risk developing a tendency to use the first language as a crutch, particularly during critical situations. Further, instructors may teach using the first language rather than English, reducing the opportunity for the student to develop their English skills. As an alternative solution, flight schools could invest in training their own instructors, NES and NNES alike, to become more ELF-aware and develop accommodation skills.

All interviewees indicated pronunciation as the main cause of miscommunication. For example, one of the informants reported that "they (the locals) have their own English voice; it's a little bit different 
from the way we speak". Pronunciation issues have been investigated particularly in relation to RTF and identified as potential causes of misunderstandings (KIM; ELDER, 2009; MOLESWORTH; ESTIVAL, 2015). Based on a survey conducted by EuroControl in 2006, Bieswanger (2019) highlights pronunciation-related problems connected with controller accent and controller speech rate as "the two top factors causing similar call sign communication occurrences".

The review of literature on recent ELF research presented in Section 2 shows that most scholars have come to the conclusion that there is no teachable international ELF accent. Proposing alternatives for the preparation of NNES ab initio pilots is not trivial. Strategies of ELF-aware language teaching and learning, such as the ones proposed by Sifakis (2019; cf. also KAUR 2019), could be included in such courses. According to Sifakis (2019: 291), particularly important elements are the "awareness of the processes of languaging (the process of using communication strategies, such as negotiation, to produce meaningful interactions [...]) and translanguaging (the process of using multiple linguistic and nonlinguistic resources to ensure efficient communication between multilingual interlocutors [...]). However, it has to be assumed that many NES stakeholders will not develop an adequate amount of ELF awareness and the additionally necessary accommodation skills in the foreseeable future. This means that the preparation of NNES ab initio pilots also has to include an orientation towards an active command of one of the well-codified and internationally widely understood accents common in the English-language classrooms, and learners should be confronted with a range of different native and non-native accents of English. Matsuura et al. (2014) have shown for ELF interactions that familiar accents are easier to understand, even at a higher speech rate.

\section{Conclusion}

The recent and projected increase in demand for pilots, particularly in areas of the world where English is traditionally not the native language of most of the population, leads to a constantly growing number of NNES student pilots in flight schools in English-speaking countries. Among other things, flight schools in English-speaking countries are popular with NNES flight students, because they hope to develop flying skills at the same time as they are improving their English proficiency, which is a requirement for all pilots flying internationally. However, semi-structured interviews conducted with six pilots - three Brazilian and three Chinese - and other reports point to the fact that many NNES ab initio flight students face communication-related difficulties at flight schools in English-speaking countries and some cannot even successfully complete their training. This paper thus addresses two research questions, namely what communicative skills NNES flight students will need in English-speaking environments and how current research on ELF can inform the design of English for flight training courses for them. 
The study shows that many NNES flight students do not have adequate linguistic and strategic skills to cope with life and flight school in an English-speaking country, and that many NES instructors lack accommodation skills to provide necessary help. For most of the 2000s, the early period of ELF research, many scholars believed that an international variety of English could be described, codified and eventually taught to learners of English, which would have been the natural choice for the globally operating aviation industry. However, more recent ELF research has shown that there are no universally teachable features of ELF and so alternative suggestions have to be proposed, in this case for the preparation of NNES ab initio flight students who want to to pursue flight training in an English-speaking environment. Assuming that the development of accommodation skills among many NES instructors will be slow, as it is usually not a mandatory part of their training, NNES have to be enabled, at least for the foreseeable future, to communicate with NESs - ideally before they start flight training in an Englishspeaking environment. English courses for flight training should thus, on the one hand, include the learning of communicative strategies often summarized under the umbrella term ELF awareness (see Section 5). On the other hand, these courses cannot neglect the linguistic skills - such as basic structures of English, the active command of a widely understood accent of English and passive familiarization with a variety of different accents - necessary for efficient and effective communication in English, as even the best knowledge of strategic skills cannot fully make up for a severe lack of language proficiency. The focus concerning both aspects should be placed on spoken communication, particularly in countries where written communication is still dominant and oral skills are frequently neglected in the regular language classroom. Additionally, future flight students who plan to do their training in an English-speaking environment should be convinced that an early acquisition of linguistic and strategic skills, i.e. communicative competence, is an important asset for flight training and their further career, and not a waste of time and resources.

\section{References}

BIBER, D.; S. CONRAD. 2009. Register, genre and style. Cambridge: Cambridge University Press. BIESWANGER, M. 2013. Applied linguistics and air traffic control: Focus on language awareness and intercultural communication. In SCHIRRA-HANSEN, S.; K. MAKSYMSKI (Eds.), Aviation Communication: Between Theory and Practice. Frankfurt am Main et al.: Lang. 15-31.

BIESWANGER, M. 2016. Aviation English: Two distinct specialized registers? In SCHUBERT, C.; C. SANCHEZ-STOCKHAMMER (Eds.), Register Revisited: New Perspectives on Functional Text Variety in English. Berlin \& Boston: de Gruyter. 67-85.

BIESWANGER, M. 2019. How research on English as a lingua franca can help to identify and address new training needs of the changing aviation community. International Civil Aviation English Association 4. Available at: $<$ https://commons.erau.edu/icaea-workshop/2019/day-1/4>. Access: 30 Jul 2020 . 
BOEING. 2019. Pilot and technician outlook 2019-2038. Available at:

$<$ https://www.boeing.com/commercial/market/pilot-technician-outlook/>. Access: 30 Jul 2020.

BOUFLEUER, L. 2019. English usage along the commercial pilot's course: the perspective of Brazilian student pilots. In PACHECO, A. (Ed.) English for aviation: guidelines for teaching and introductory research. EdiPUCRS.

BROWN, H.; A. BRADFORD. 2016. EMI, CLIL, \& CBI: Differing Approaches and Goals. Japan Association for Language Teaching, Winc Aichi, Nagoya, Japan. Available at: $<$ http://jaltpublications.org/sites/default/files/pdf-article/jalt2016-pcp-042.pdf > . Access: 30 Jul 2020.

CABAU, B. 2014. Optimizing the benefits of overseas academic sojourns: pre-departure training for exchange students. In PARADOWSKI, M.B. (Ed.) Teaching languages off the beaten track. Bern, Switzerland: Peter Lang, p. 189-208.

DAVIES, C. 2004. Developing awareness of crosscultural pragmatics: The case of American/German sociable interaction. Multilingua, 23:207-231.

DUSENBURY, M.; E. BJERKE. 2013. Predictive power of English Testing: Training international flight students. Journal of Aviation/ Aerospace Education \& Research, 23.1. Available at:

$<$ https://commons.erau.edu/jaaer/vol23/iss1/5/>. Access: $30 \mathrm{Jul} 2020$.

EMERY, H. 2015. Aviation English for the next generation. In BOROWSKA, A.; E. ADRIAN (Eds.)

Changing perspectives on aviation English training. Warsaw: University of Warsaw. p. 8-34.

EMERY, H.; D. GLIDDON. 2019. ICAO Level 4 for Flight Training Admissions: A Square Peg in a

Round Hole? International Civil Aviation English Association. 3. Available at:

$<$ https://commons.erau.edu/icaea-workshop/2019/day-2/3/>. Access: 30 Aug 2020.

ESTIVAL, D.; C. FARRIS; B. MOLESWORTH. 2016. Aviation English: A lingua franca for pilots and air traffic controllers. Oxford: Routledge.

FARRIS, C. 2007. The effects of message length, L2 proficiency and cognitive workload on performance accuracy and speech production in a simulated pilot navigation task. Master thesis, Concordia University, Montreal.

Federal Aviation Administration (FAA). 2013. English Language Skill Standards Required by 14 CFR Parts 61, 63, and 65. (AC No: 60-28A).

FRIGINAL, E.; E. MATHEWS; J. ROBERTS. 2020. English in Global Aviation: Context, Research, and Pedagogy. London: Bloomsbury.

GORBOLD, D. 2017. One country- multiple training and testing pathways: the effects on test takers, testing systems and English language proficiency". International Civil Aviation English Association. Available at: $<$ https://commons.erau.edu/icaea-workshop/2017/monday/16/>. Access: 31 Jul 2020.

HOFFMAN, T. 2020. Aviation English, Please. Federal Aviation Administration Safety Briefing. Available at: $<$ https://www.faa.gov/news/safety briefing/2020/media/MayJun2020.pdf $>$. Access: 30 Jul 2020.

International Civil Aviation Organization (ICAO). 2010. Manual on the implementation of the language proficiency requirements (Document9835-AN/453) (2nd ed.). Montreal: International Civil Aviation Organization.

JENKINS, J. 2000. The Phonology of English as an International Language. Oxford: Oxford University Press.

JENKINS, J. 2002. A sociolinguistically based, empirically researched pronunciation syllabus for English as an international language. Applied Linguistics 23.1: 83-103.

JENKINS, J. 2009. English as lingua franca: interpretations and attitudes. World Englishes, 28.2: 200207.

JENKINS, J. 2015. Repositioning English and multilingualism in English as a lingua franca. Englishes in Practice, 2.3: 49-85.

JENKINS, J.; A. COGO; M. DEWEY. 2011. Review of developments in research into English as a lingua franca. Language Teaching, 44.3: 281-315. 
KAUR, J. 2019. Communication strategies in English as a Lingua Franca interaction. In PETERS, M. A.; R. HERAUD (Eds.) Encyclopedia of Educational Innovation. Singapore: Springer, 1-5.

KAY, M. 2018. Developing Cross-Cultural Communicative Competence International Civil Aviation English Association. 18. Available at: $<$ https://commons.erau.edu/icaeaworkshop/2018/wednesday/18>. Acess: 03 Aug 2020.

KIM, H. 2018. What constitutes professional communication in aviation: Is language proficiency enough for testing purposes? Language Testing, 35.3: 403-426.

KIM, H.; C. ELDER. 2009. Understanding aviation English as a lingua franca: Perceptions of Korean aviation personnel. Australian Review of Applied Linguistics, 32.3:23.1-23.17.

KALOCSAI, K. 2009. Erasmus exchange students: A behind-the-scenes view into an ELF community of practice. Apples - Journal of Applied Language Studies, 3.1:25-49.

LYNCH, J.; A.M. PORCELLATO. (this volume). The case for an aviation English screening tool for U.S. flight schools.

MATSUURA, H.; R. CHIBA; S. MAHONEY; S. RILLING. 2014. Accents and speech rate effects in English as a Lingua Franca. System, 46:143-150.

MAURANEN, A. 2018. Conceptualising ELF. In JENKINS, J.; W. BAKER; M. DEWEY (Eds.) The Routledge handbook of English as a lingua franca. New York: Routledge, 7-24.

MODER, C. L. 2013. Aviation English. In PALTRIDGE, B.; S. STARFIELD (Eds.), The

handbook of English for specific purposes. Malden: John Wiley \& Sons, 227-242.

MOLESWORTH, B.; D. ESTIVAL. 2015. The influence of external factors on communication errors.

Safety Science, 73:73-79.

MONTEIRO, A. L. 2019. Reconsidering the measurement of proficiency in pilot and air traffic controller radiotelephony communication: From construct definition to task design. Doctoral thesis, Carleton University. Available at: <https://curve.carleton.ca/0b65cc09-37d2-449f-804d-a6f804917927>. Access: 31 Jul 2020.

PRADO, M. 2019. A relevância da Pragmática no ensino do inglês aeronáutico: um estudo baseado em corpora. Doctoral thesis. Department of Modern Languages, University of São Paulo. Available at: $<$ https://www.teses.usp.br/teses/disponiveis/8/8147/tde-16122019-181408/pt-br.php>. Access: 31 Jul 2020.

ROBERTS, J.; A. ORR. 2020. Language Education for Ab Initio Flight Training: A Plan Going Forward. In KEARNS, S.; T. MAVIN; S. HODGE (Eds.), Engaging the Next Generation of Aviation Professionals. New York: Routledge.

RAJAGOPALAN, K. 2005. Non-native speaker teachers of English and their anxieties: ingredients for an experiment in action research. In E. LLURDA (Eds.) Non-native language teachers. Boston, MA: Springer.

SEIDLHOFER, B. 2004. Research perspectives in teaching English as a lingua franca. Annual Review of Applied Linguistics, 24: 209-239.

SEIDLHOFER, B. 2005. English as a lingua franca. ELT Journal 59(4): 339-341

SIFAKIS, N. C. 2019. ELF awareness in English language teaching: Principles and processes. Applied Linguistics, 40.2: 288-306.

TOSQUI-LUCKS, P.; A. L. B. C. SILVA. 2020. Da elaboração de um glossário colaborativo à discussão sobre os termos "inglês para aviação" e "inglês aeronáutico". Revista Estudos Linguísticos 49.1: 97-116. Available at: <https://revistas.gel.org.br/estudos-linguisticos/article/view/2561/1676>. Access: 06 Aug 2020.

Markus Bieswanger is professor of English Linguistics at Bayreuth University, Germany, head of the scientific steering committee of the Bayreuth University Language Center, which offers courses and proficiency assessment in more than 20 languages, and an Aviation English consultant. He has a long- 
standing and well-documented research interest in Aviation English - including language teaching, learning and testing, the use of English as a Lingua Franca and aspects of intercultural communication in many contexts including aviation - and has done consultant work for several airlines and air traffic control providers. Email address: markus.bieswanger@uni-bayreuth.de

Malila Prado is professor in the School of Humanities at Fujian University of Technology, China. She has worked as an English language teacher for over 20 years, specializing in the field of aviation English since 2008. She holds a Master's Degree and PhD from the Department of Modern Languages of Universidade de Sao Paulo (Brazil), examining the language used by pilots and air traffic controllers in abnormal situations through corpus linguistics. She is a member of Grupo de Estudos em Inglês Aeronáutico (GEIA) based in Brazil.Email address: malilaprado@hotmail.com

Jennifer Roberts works in the College of Aeronautics at Embry-Riddle Aeronautical University (USA), as an Aviation English Specialist. Her primary focus is the development and implementation of Aviation English programs in face-to-face and online modalities. Prior to her role at Embry-Riddle, she completed an MA in Applied Linguistics and ESL at Georgia State University (USA) and served as an English Language Fellow in Indonesia. Her research interests include the pedagogical applications of corpus linguistics, particularly in English for Specific Purposes settings, and language policy and planning.Email address: roberj62@erau.edu 